Portland State University

PDXScholar

\title{
Development of Future Land Cover Change Scenarios in the Metropolitan Fringe, Oregon, U.S., with Stakeholder Involvement
}

Heejun Chang

Portland State University, changh@pdx.edu

Roberrt W. Hoyer

Portland State University, r.wesley.hoyer@gmail.com

Follow this and additional works at: https://pdxscholar.library.pdx.edu/geog_fac

Part of the Nature and Society Relations Commons, and the Urban Studies and Planning Commons Let us know how access to this document benefits you.

Citation Details

Hoyer, Robert W., and Heejun Chang. "Development of Future Land Cover Change Scenarios in the Metropolitan Fringe, Oregon, US, with Stakeholder Involvement." Land 3.1 (2014): 322-341.

This Article is brought to you for free and open access. It has been accepted for inclusion in Geography Faculty Publications and Presentations by an authorized administrator of PDXScholar. Please contact us if we can make this document more accessible: pdxscholar@pdx.edu. 
Article

\title{
Development of Future Land Cover Change Scenarios in the Metropolitan Fringe, Oregon, U.S., with Stakeholder Involvement
}

\section{Robert W. Hoyer and Heejun Chang *}

Department of Geography, Portland State University, P.O. Box 751, Portland, OR 97207, USA; E-Mail: r.wesley.hoyer@gmail.com

* Author to whom correspondence should be addressed; E-Mail: changh@pdx.edu; Tel.: +1-503-725-3162; Fax: +1-503-725-3166.

Received: 26 November 2013; in revised form: 26 February 2014 / Accepted: 6 March 2014 /

Published: 14 March 2014

\begin{abstract}
We describe a future land cover scenario construction process developed under consultation with a group of stakeholders from our study area. We developed a simple geographic information system (GIS) method to modify a land cover dataset and then used qualitative data extracted from the stakeholder storyline to modify it. These identified variables related to our study area's land use regulation system as the major driver in the placement of new urban growth on the landscape; and the accommodation of new population as the determinant of its growth rate. The outcome was a series of three scenario maps depicting a gradient of increased urbanization. The effort attempted to create a simple and transparent modeling framework that is easy to communicate. The incorporation of the regulatory context and rules and place-specific modeling for denser urban and sparse rural areas provide new insights of future land conversions. This relatively rapid mapping process provides useful information for spatial planning and projects for where and how much urban land will be present by the year 2050 .
\end{abstract}

Keywords: land cover change; urbanization; scenarios; stakeholder participation; GIS

\section{Introduction}

Human pressures on the environment have their most apparent manifestation in the visible transformation of the Earth's surface. Over the last 50 to 100 hundred years, the most important factor 
in the change in terrestrial ecosystems has been land cover conversion [1,2], and this trend is likely to continue in the future [3]. Land use/land cover (LULC) maps offer a way to document and quantify these changes [4]. Technological improvements over the last several decades have enhanced LULC maps' ability to observe the outcomes of social and ecological processes on the landscape [5]. Projecting LULC patterns into the future can be a useful exercise for evaluating how these processes change and identifying potential consequences. Creating a series of possibilities given the available information can provide insights for spatial planning. These possibilities or scenarios provide a useful way to sketch out the future with a level of plausibility "while explicitly incorporating relevant science, societal expectations, and internally consistent assumptions about major drivers, relationships, and constraints" [6]. LULC change scenarios are important, because these can be used to evaluate the potential environmental impacts of decisions or policy shifts $[7,8]$.

In many instances, scenario creation is expert- and/or model-driven, and researchers make the case for their utility to end users [9-12]. This is problematic in a case with high stakes and high uncertainty, as with land use. Decision makers often prefer their own judgment to model results, highlighting the need for a model to be transparent and simple [13]. Using a participatory approach can partly relieve this issue. Stakeholder and public participation legitimizes the process and justifies the use of the outcomes for planning and decision-making [14]. A key issue in scenario-building methods is the integration of stakeholder-derived qualitative data (typically in the form of a storyline) into models that require quantitative data to produce the final output [15]. There are strategies proposed to formally bridge this divide, like fuzzy cognitive maps [16]. However, in some practical cases, where LULC change is a large component of the final scenarios, an intuitive conceptual approach is used to translate qualitative storylines to quantitative input [17-19]. Our study follows a similar approach to these.

The research objective is to develop maps of future LULC scenarios for the study area involving stakeholders. For this research, we define stakeholders as members of organizations with interests in LULC change within the study area [20]. Other researchers created LULC maps in the region for a larger area using a participatory method [21]. This work required several years with numerous iterations that struck a balance in defining assumptions along a gradient of citizen engagement and expert opinion for mapping outcomes to reach satisfactory results. The trend in scenario-building studies is that they are typically a time-intensive process. In an attempt to produce an LULC map relatively quickly, while still retaining the benefits of a participatory approach, we used a simple framework that integrated input from stakeholders with local knowledge into a geographic information system (GIS) modeling process. We took information gathered from a single workshop, as well as a few additional one-on-one conversations and used these as guiding principles for future land cover change. In this respect, our study is more a consultation than an engagement process, but it is a useful method for addressing an important problem in our research program. Although we anticipate more development along the urban-rural fringe in our study area, it is currently unknown where and how much new development will be placed specifically. 


\section{Methods}

\subsection{Study Area}

The Tualatin and Yamhill basins drain a portion of the Willamette Valley's northwest corner and are 1858 and $2000 \mathrm{~km}^{2}$, respectively (Figure 1). The area holds the three broad land typologies of western Oregon - developed lands, agriculture and natural vegetation dominated by upland forests. A significant portion of the Tualatin basin lies in the greater Portland metropolitan area. Washington and Yamhill counties, whose areas approximately correspond to the majority of the study area, have experienced rapid growth since 1980 (Table 1) [22], continuing a legacy of population growth in the Portland metropolitan area over the last century [23]. The city of Hillsboro, a west Portland suburb, has more than tripled in population between 1980 and 2010. Washington County is seeing higher population density increase than the average for all counties of the north Willamette Valley region (Figure 2) [24]. Despite higher density, urban land cover continues to grow in the study area as population increases (Table 2) [25,26].

Table 1. Populations by decade for two counties and select cities in the study area.

\begin{tabular}{ccccccc}
\hline & Pop. 1980 & Pop. 1990 & Pop. 2000 & Pop. 2010 & Ann. Ave. Change & Total Change \\
\hline County & & & & & & \\
\hline Washington & 245,860 & 311,554 & 445,342 & 529,710 & $2.39 \%$ & $115.4 \%$ \\
Yamhill & 55,332 & 65,551 & 84,992 & 99,193 & $1.90 \%$ & $79.3 \%$ \\
\hline Large Cities & & & & & & \\
\hline Beaverton & 31,962 & 53,307 & 76,129 & 89,803 & $3.39 \%$ & $181.0 \%$ \\
Hillsboro & 27,664 & 37,598 & 70,186 & 91,611 & $3.94 \%$ & $223.2 \%$ \\
McMinnville & 14,080 & 17,894 & 26,499 & 32,187 & $2.70 \%$ & $128.6 \%$ \\
Newberg & 10,394 & 13,086 & 18,064 & 22,068 & $2.46 \%$ & $112.3 \%$ \\
\hline
\end{tabular}

To understand the drivers of the area's land cover change, a discussion of the policy context is warranted, as institutional factors mediate people's response to economic opportunities [27]. In 1973, the Oregon legislature created an institutional framework for land-use planning applying state-wide goals informed by citizens and implemented through local governments [28]. This regulatory environment was meant to first protect Oregon farmlands and also encouraged livable urban communities with well-planned infrastructure. A primary tool towards this end was an urban growth boundary (UGB) for each incorporated city to reduce urban sprawl and encourage future compact development. These UGBs effectively create a land use dichotomy of urban lands within and the resource lands on the outside. In 2004, the passage of state ballot Measure 37 allowed a compensation claim or waiver of development restrictions for property acquired prior to the enactment of the legislation [29]. Land use planning advocates convinced voters to replace it with Measure 49 in 2007. It provides a more rigorous definition of compensation by limiting claims to three or less new dwellings on a parcel. In 2007, Metro, the Portland regional governing agency, proposed urban and rural reserve areas (URAs and RRAs) surrounding the current UGB to plan for growth in a manner compatible with state land use goals, which include targeting areas for future development that limit impacts on ecological systems [30]. These basins and the Tualatin in particular have also come under a high level of scrutiny 
for water quality issues [31,32]. Both basins have stream reaches placed on the state's 303(d) list for impaired surface water bodies in accordance with the federal Clean Water Act. Total Maximum Daily Loads (TMDLs) are in place or in development for several water quality indicators [33]. LULC plays a major role in determining water quality indicator values and stream health within both urbanizing and agricultural catchments in the study area [34,35].

Figure 1. Study area, including the current urban growth boundaries around each municipality.

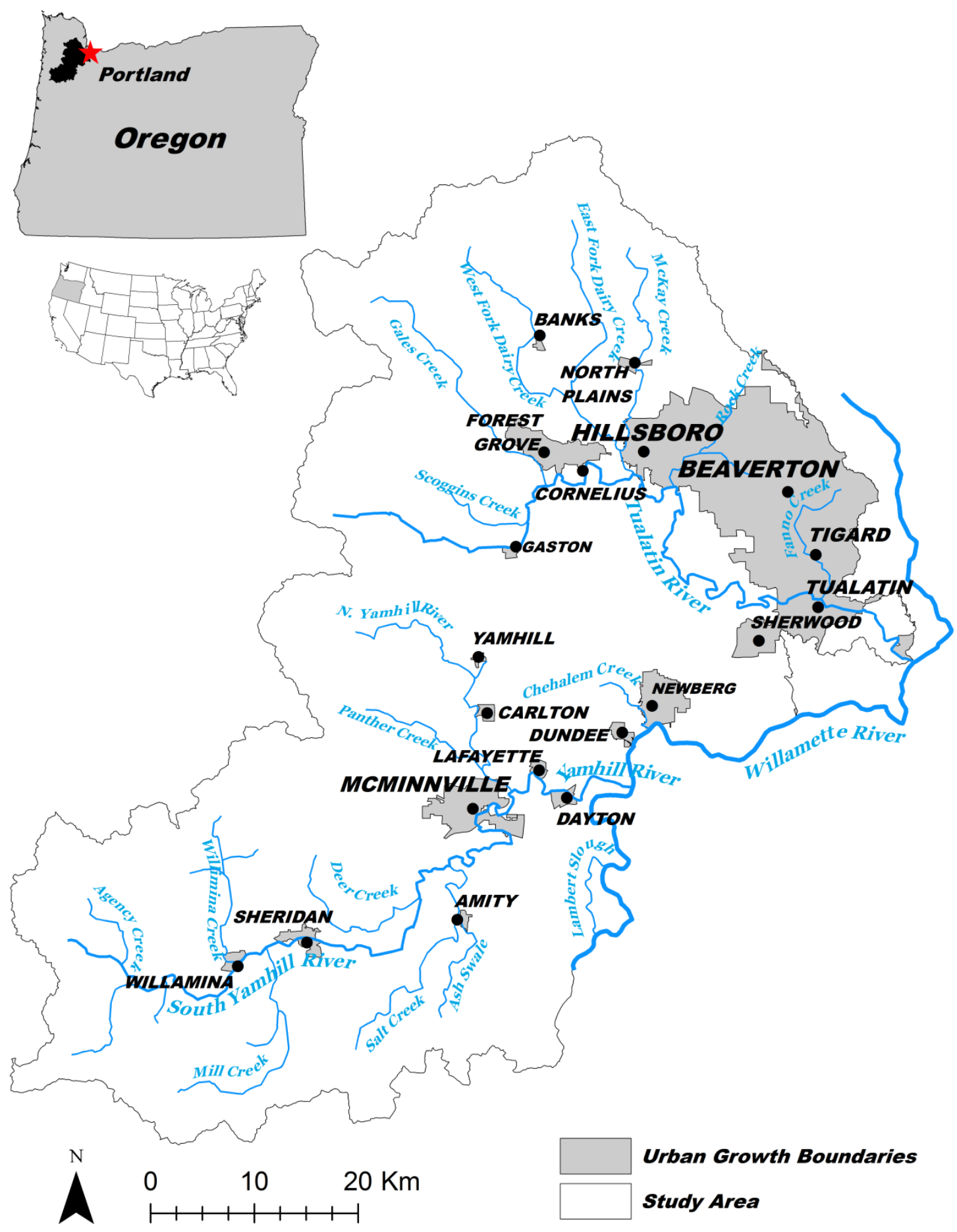


Figure 2. Annual increase in population density (people/ha) for two counties. The six Oregon counties of the northern Willamette Basin (Clackamas, Columbia, Marion, Multnomah, Washington and Yamhill Counties) are included for reference. Data are from Portland State College of Urban and Public Affairs Population Research Center.

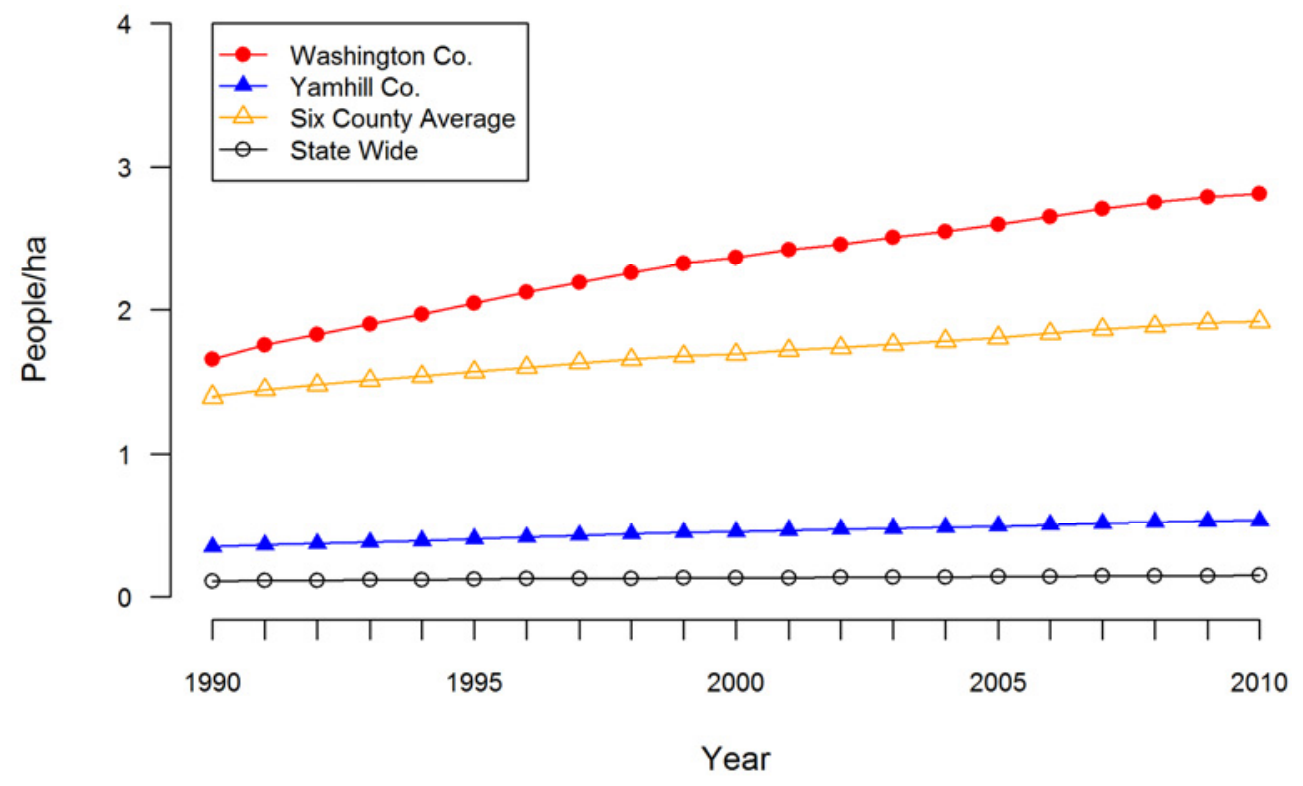

Table 2. Change in urban land cover classes for two counties and select cities in the study area. Change based on National the Land Cover Dataset (NLCD) 1992-2001 land cover change retrofit product [34] and the 2001 and 2006 NLCD datasets.

\begin{tabular}{ccccc}
\hline & $\begin{array}{c}1992 \text { to 2001 Urban } \\
\text { Change (ha) }\end{array}$ & $\begin{array}{c}\text { Percent } \\
\text { Change }\end{array}$ & $\begin{array}{c}\text { 2001 to 2006 Urban } \\
\text { Change (ha) }\end{array}$ & $\begin{array}{c}\text { Percent } \\
\text { Change }\end{array}$ \\
\hline County & & & & \\
Washington & 1209 & $4.3 \%$ & 1073 & $3.0 \%$ \\
Yamhill & 260 & $20.8 \%$ & 381 & $3.0 \%$ \\
Large Cities & & & & \\
Beaverton & 108 & $2.5 \%$ & 43 & $1.0 \%$ \\
Hillsboro & 293 & $6.5 \%$ & 288 & $5.8 \%$ \\
McMinnville & 34 & $1.8 \%$ & 138 & $7.2 \%$ \\
Newberg & 89 & $8.1 \%$ & 43 & $10.9 \%$ \\
Study Area & 1669 & $3.1 \%$ & 1476 & $2.7 \%$ \\
\hline
\end{tabular}

\subsection{Data}

We chose the USGS National Land Cover Dataset (NLCD) 2006 as the baseline land covers in our study area for a variety of reasons [26]. First, the dataset contains a manageable amount of classifications, with 15 falling within the study area. Second, at 30-m resolution, it allows a fair degree of spatial differentiation without overwhelming the subsequent modeling efforts. Third, the year 2006 is the most up-to-date product available from the USGS. The socioeconomic calculations for this project started in 2010 to align with U.S. Census estimates. Considering the late decade economic downturn slowing of new development, we assumed the four-year difference in land cover would be 
small at the landscape scale. Several other datasets were gathered from various state and local agencies and governments [36-39]. As the focus was on the increase in urban development, most of the data was primarily composed of spatially explicit data pertaining to the Oregon land use regulation framework (Table 3).

Table 3. Data sources used to create a spatial mask and graded weight map used as inputs to a model, creating future scenario maps in the study area.

\begin{tabular}{|c|c|c|}
\hline Data Type & Description & Sources \\
\hline $\begin{array}{l}\text { Urban Growth } \\
\text { Boundaries } \\
\text { (UGB) }\end{array}$ & $\begin{array}{l}\text { Includes current UGB plus accepted and proposed } \\
\text { urban reserve areas (URAs), rural reserves with } \\
\text { additional protection and some additional adjacent } \\
\text { land in case growth exceeds current reserves. }\end{array}$ & $\begin{array}{l}\text { Metro Regional Land and } \\
\text { Information System (RLIS), } \\
\text { City of McMinnville Planning } \\
\text { Department, } \\
\text { City of Newberg Engineering } \\
\text { Department }\end{array}$ \\
\hline Zoning & $\begin{array}{l}\text { Includes all except a few small communities. A } \\
\text { statewide layer designating broad classifications } \\
\text { (forestry, agriculture and rural residential) was } \\
\text { integrated with municipality zoning layers. }\end{array}$ & $\begin{array}{l}\text { RLIS, Mid-Willamette Valley } \\
\text { Council of Governments } \\
\text { (City of Dayton's zoning estimated } \\
\text { from online map) }\end{array}$ \\
\hline $\begin{array}{l}\text { Measure } 49 \\
\text { Claims }\end{array}$ & $\begin{array}{l}632 \text { claims joined to tax lot parcel data to make } \\
\text { spatially explicit. Authorized claims collected from } \\
\text { three counties making up the vast majority of the } \\
\text { study area. }\end{array}$ & $\begin{array}{l}\text { Oregon Department of Land } \\
\text { Conservation and Development, } \\
\text { State of Oregon Geospatial } \\
\text { Enterprise Office, Yamhill County } \\
\text { Assessor's Office }\end{array}$ \\
\hline $\begin{array}{l}\text { High Value } \\
\text { Farm Soils }\end{array}$ & $\begin{array}{l}\text { Agriculture soils of U.S. Natural Resource } \\
\text { Conservation Service Class I and II (irrigated or non- } \\
\text { irrigated) }\end{array}$ & Oregon Spatial Library \\
\hline $\begin{array}{l}\text { Groundwater } \\
\text { Restriction } \\
\text { Zones }\end{array}$ & $\begin{array}{l}\text { Critical and restricted groundwater zones could } \\
\text { possibly be an impediment to rural residential } \\
\text { development. Designated by the Oregon Department } \\
\text { of Water Resources where aquifers are identified as } \\
\text { depleted or used at an unsustainable rate }\end{array}$ & $\begin{array}{l}\text { Oregon Department of Water } \\
\text { Resources }\end{array}$ \\
\hline Protected Areas & $\begin{array}{l}\text { Lands off-limits to development for a variety of } \\
\text { reasons, including federal forest lands, city and state } \\
\text { parks, private green spaces and schools. }\end{array}$ & $\begin{array}{l}\text { RLIS, U.S. Fish Wildlife Geospatial } \\
\text { Services }\end{array}$ \\
\hline
\end{tabular}

\subsection{Construction of Scenarios with Stakeholder Consultation}

Our modeling framework followed a multistage process (Figure 3). Using a previously published approach, we elicited opinions on our modeling process from a small group of stakeholders. The researchers took the view that in their limited role, stakeholders would serve to validate assumptions the researchers made in creating maps, or if they distrusted the results, we could make improvements. Swetnam et al. [18] used a rules-based framework for integrating stakeholder narrative data into a quantitative geographic information system (GIS) modeling method. We produced an initial LULC map projected for the year 2050 using this method with data and rules defined by the researchers. The initial rate of changes in land cover types were estimated through an extrapolation of the differences 
detected in the NLCD 1992-2001 land cover change retrofit product [25], as well as the 2006 NLCD product.

Figure 3. Conceptual diagram of the stakeholder consultation process informing the development of the modeling approach used to produce future land cover scenarios. AHP, pairwise analytical hierarchy process.

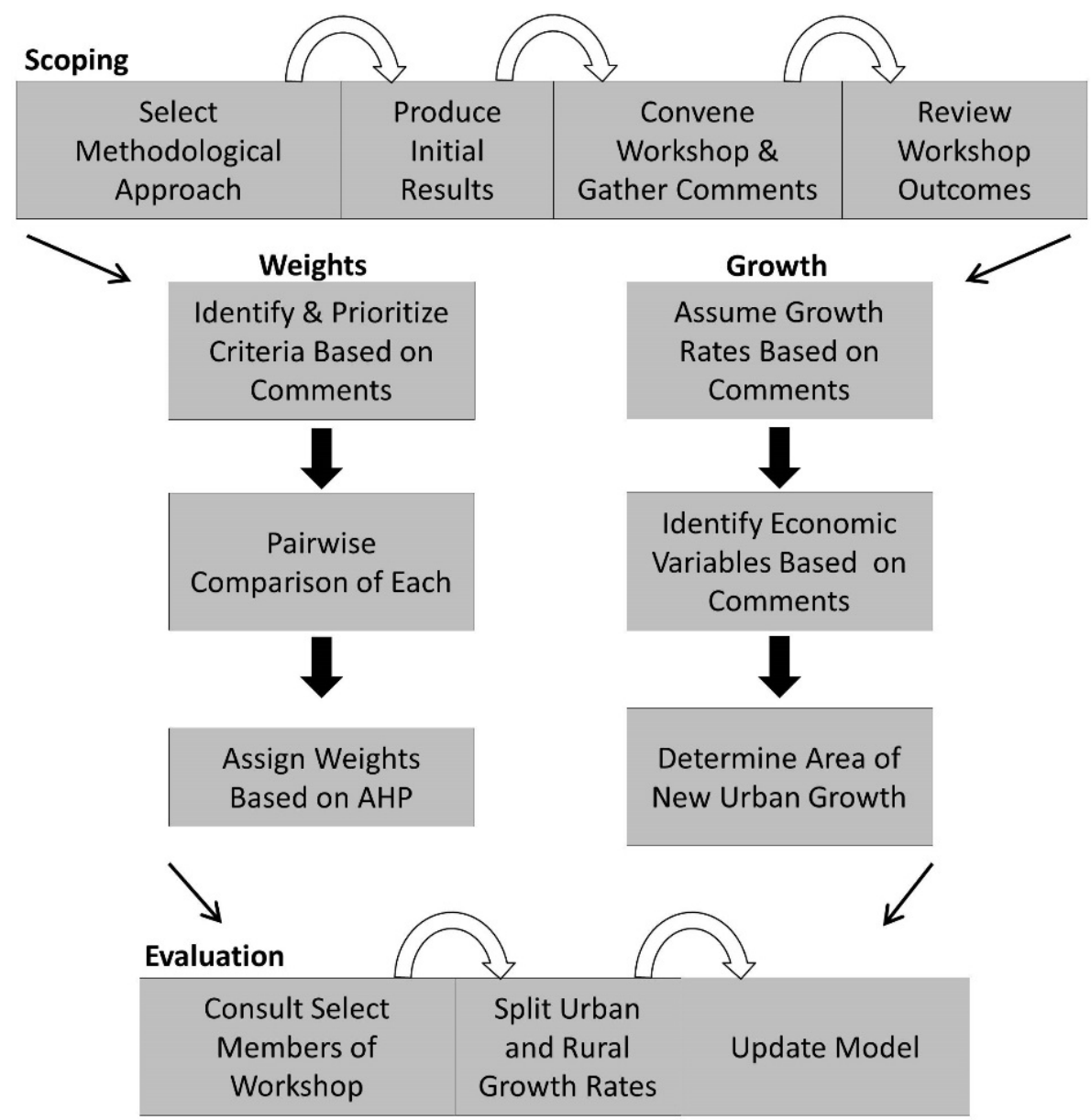

The researchers convened a workshop in June 2012, that lasted several hours. A project partner involved with the current environmental issues in our study area chose four professionals for the consultation. They represented a cross-section of land use interests, including a representative from the Oregon Department of Agriculture, a county planner, an economist with Portland Metro administrative and planning agency and a land use attorney. We presented the project background information and the LULC modeling method and initial maps. Workshop participants initially discussed what they knew about land use in the region. The workshop then evolved into discussion about the future of developed lands in the study area and the factors they considered relevant.

As the discussion progressed, it became evident that the participants' opinions pointed to the state land use regulatory framework being the primary factor deciding where new developed land would be located over the next several decades. It yielded other important points. Any large increases of farmland were unlikely given that almost all suitable lands were already in production. County planners worked hard to maintain rural landscapes, so although conversion of farmlands will occur, they will be too small to fundamentally alter the land cover type present. Based on these participants' 
inputs, we decided to focus on new urban development in our modeling effort. They quickly agreed that the UGB was the most important factor, followed by the Oregon Department of Water Resources groundwater restriction zones [40], high value farm soils [41], zoning and Measure 49 claims. These factors are readily available or adaptable to spatial datasets (Table 3). In our subsequent scenario maps, participants replaced the criteria chosen by the researcher in the initial map that included a few biophysical factors, like soil type and slope.

For quantifying new urban growth, we relied on the two planner participant comments that made the link between urban growth and the accommodation of new population. They suggested basing the estimated amount of required new urban area on population growth and a few demographic variables. When asked for rates of population growth within the range of plausibility, we received a single volunteered response of roughly $0.5 \%$ to $2.5 \%$, which we adapted to $0.6 \%, 1.5 \%$ and $2.0 \%$ for the construction of future scenarios. This is supported by the known increases in observed growth over the previous decades (Tables 2 and 3).

We performed some simple calculations to link population to urban development, based on consultation with planning professionals who participated in the workshop. These included future average household size (2.46) [23], an estimated employment-population (e-p) ratio (0.44) consistent with 2010 population and jobs numbers [42,43], employment per household (1.2) and an estimated density of future jobs and residences. Employment per household was a slight modification of the rule of thumb of one job per household suggested by one. Both planners anticipated a modest increase in job density in the future and smaller residential lot sizes and higher density housing developments in the upcoming decades. The researchers chose an employment density metric slightly higher than a current estimate using the e-p ratio and the NLCD 2006 high development category. This was regarded as plausible, as many employment facilities will continue to be low density, like warehouses. One participant mentioned a current density target for housing (approximately 35 per ha). We chose a somewhat higher figure (42 per ha) to account for the existing urban area absorbing a small portion of the additional needed residences and the additional comment that density targets are likely to increase in the future under political pressure. The additional required land averaged with the current urban land base yielded small to moderate increases in urban densification (Table 4).

To allocate area to NLCD's different developed cover classes, we assumed that the proportional relationship between open, low and medium development would hold from current conditions. The open development class in our study area typically covers urban greenspaces, such as city parks, large lawns and golf courses. Low and medium classes cover the majority of residential areas. A final modification was suggested again by the planners to split the growth between urbanizing and traditionally rural areas. The sentiment communicated to the researchers was that the regulatory framework would discourage growth in rural areas to the point that it would be very small over the coming decades. At the workshop, participants agreed that very small "cities" are unlikely to expand for cultural, social, economic and infrastructural reasons. As a consequence of this observation, the study area was split into medium to large urban areas and the rest of the landscape. One participant suggested dividing the growth to $95 \%$ urban and 5\% rural (Table 4). Job densities are higher in rural areas than urban areas, because the job densities were artificially compressed into the small amount of present urban land cover. We summarize the final increases of new developed area from NLCD 2006 to the future scenario in Table 5. 
Table 4. Summary of the metrics used to calculate area of new urban land cover by the year 2050 .

\begin{tabular}{ccccccc}
\hline Scenario & Area & $\begin{array}{c}\text { Ann. Pop. } \\
\text { Growth }\end{array}$ & $\begin{array}{c}\text { Future Jobs } \\
\text { per Ha }\end{array}$ & $\begin{array}{c}\text { Total Jobs } \\
\text { per Ha }\end{array}$ & $\begin{array}{c}\text { Future } \\
\text { Households per } \\
\text { Ha }\end{array}$ & $\begin{array}{c}\text { Total Households } \\
\text { per Ha }\end{array}$ \\
\hline $\begin{array}{c}\text { Current } \\
\text { (NLCD 2006) } \\
\text { Current }\end{array}$ & Urban & & & 82.4 & & 8.8 \\
$\begin{array}{c}\text { (NLCD 2006) } \\
\text { Future Low }\end{array}$ & Rural & & & & & 3.2 \\
Future Low & Rural & $0.57 \%$ & 86.5 & 83.5 & 42.0 & 10.4 \\
Future & Urban & $1.43 \%$ & 86.5 & 84.3 & 6.2 & 3.2 \\
Medium & & & & 42.0 & 13.3 \\
Future & Rural & $0.08 \%$ & 96.4 & 95.4 & 6.2 & 3.2 \\
$\begin{array}{c}\text { Medium } \\
\text { Future High }\end{array}$ & Urban & $1.90 \%$ & 86.5 & 84.7 & 42.0 & 14.4 \\
Future High & Rural & $0.10 \%$ & 96.4 & 95.4 & 6.2 & 3.3 \\
\hline
\end{tabular}

* The required area is based on the assumed future jobs and households per ha. The total jobs and households per ha are the density of increase averaged over both current and future urban land cover. Current land cover is based on NLCD 2006.

Table 5. Summary of growth in each developed land cover category in each future scenario expressed as total new hectares and percent increase from the USGS NCLD 2006 dataset*.

\begin{tabular}{cccccc}
\hline Scenario & & High Dev. & Medium Dev. & Low Dev. & Open Dev. \\
\hline \multirow{2}{*}{ Low } & Urban & $1250(37 \%)$ & $603(5 \%)$ & $944(5 \%)$ & $260(5 \%)$ \\
& Rural & $34(12 \%)$ & $5(1 \%)$ & $40(1 \%)$ & $64(1 \%)$ \\
\multirow{4}{*}{ Medium } & Urban & $3046(91 \%)$ & $1805(16 \%)$ & $2823(16 \%)$ & $777(2 \%)$ \\
& Rural & $41(14 \%)$ & $13(2 \%)$ & $108(4 \%)$ & $173(2 \%)$ \\
\multirow{2}{*}{ High } & Urban & $4331(129 \%)$ & $2665(24 \%)$ & $4168(23 \%)$ & $1148(23 \%)$ \\
& Rural & $44(15 \%)$ & $18(2 \%)$ & $146(2 \%)$ & $234(4 \%)$ \\
\hline
\end{tabular}

*Land use categories are based on NLCD 2006.

\subsection{Mapping}

Based on new urban lands dominating the discussion at the workshop, we chose to focus solely on new urban growth. Transitions from existing development types to higher intensity development were not considered because of time constraints and the uncertainty of future densification in the existing developed areas. While we acknowledge that changes within the current urban area will occur, like high density re-development, we assumed they would be small, based on the preservation of the existing residential area structures [44]. Thus, our model only allows new urban land cover to replace agriculture and natural vegetation types, and there are no shifts in the patterns of the remaining agriculture and natural vegetation lands. 
Figure 4. Maps of the six criteria (urban growth boundaries, distance from current urban growth boundaries, zoning, groundwater restriction zones, high value farm soils and Measure 49 claims) used to construct the graded weights map.

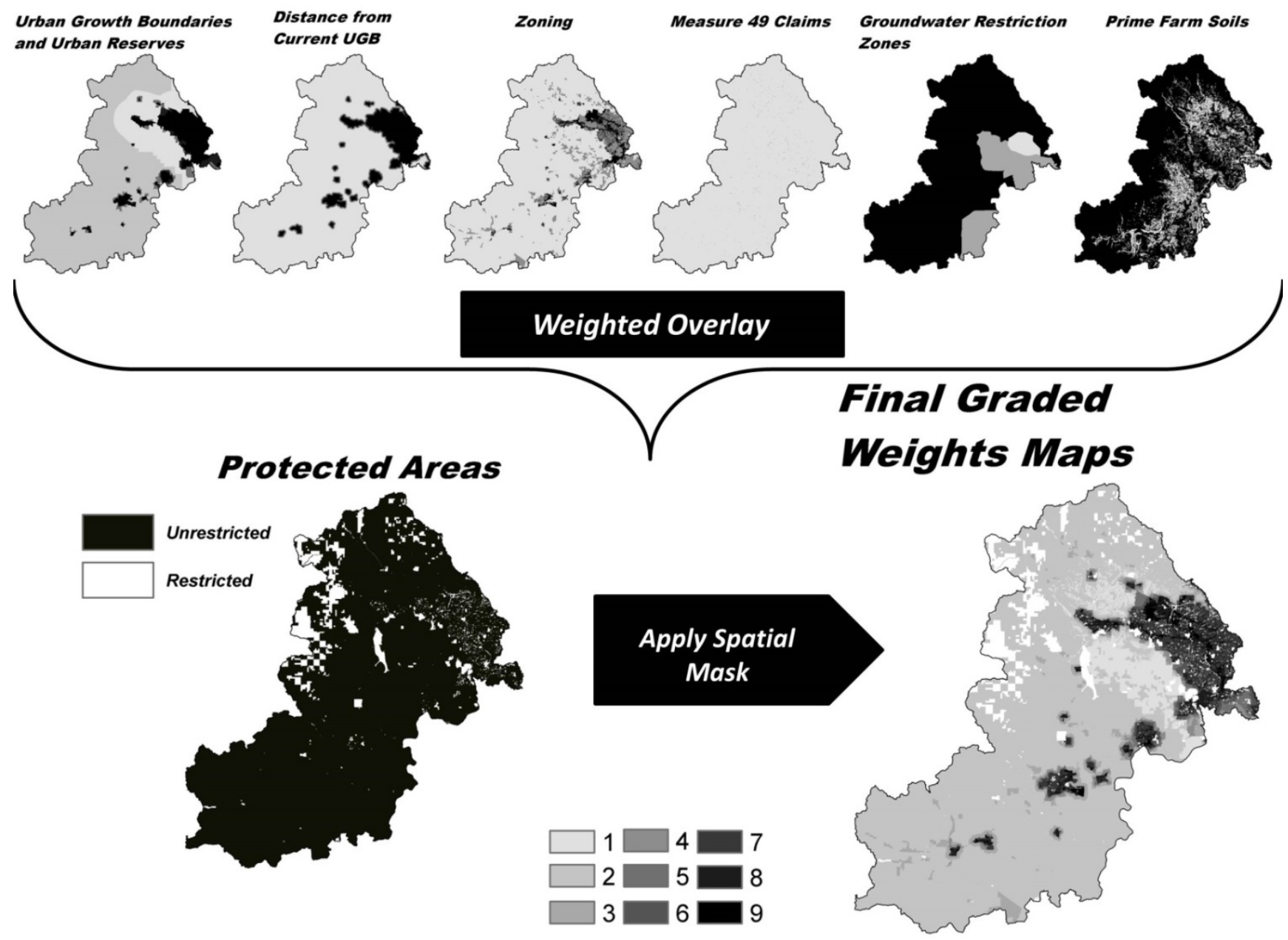

* The protected areas in the spatial mask are not eligible for land cover change, yielding the final graded map that is used to guide the assignment of new developed land cover in the study area.

The GIS process, implemented in ArcGIS 10.1 [45], used the combination of a spatial mask based on protected areas and a spatial weight map based on the regulation criteria identified by the stakeholders (Figure 4). The storyline data acquired from the workshop was not sufficiently detailed to address all the assumptions and required parameters. We interpreted the workshop discussion by identifying the criteria that were most emphasized, but also had to use the researchers' own judgment. Weight assignment was performed through a two-stage process. In the first stage, the variables within each criterion were ranked using values from nine, the highest conversion potential, to one, the lowest conversion potential. For example, the UGB criteria layer included the current UGB, URAs, undesignated lands adjacent to the UGB and RRAs. They were ranked nine, eight, five and one, respectively (Figure 4). We included a distance band from the current UGB criterion based on our judgment to preferentially assign new urban map pixels to lands closest to the UGB. Measure 49 claims were incorporated by randomly placing a small group of pixels in a claimed tax lot. This technique is likely overestimating the effect of Measure 49 claims, even though their fraction of the study area is small $(\sim 0.15 \%)$. Since it was considered an important factor by stakeholders, we did not 
eliminate it from our analysis. We assumed that the high development land cover class would consume the highest weighted pixels first, followed by the medium class, low and, finally, open. This allowed us to rank the zoning dataset from more intense land use types to least intense.

In the second phase, we calculated weights among the criteria using a pairwise analytical hierarchy process (AHP) [46]. The AHP assesses the importance of each criterion by directly comparing it to all others. For example, we assumed, based on stakeholder discussion and our judgment, that the UGB dataset will be more important than all other criteria types, but some will have more importance to it compared to others. Using the same one to nine value range, our decision was to make the UGB criteria nine times as important as prime farm soils, groundwater restriction zones and Measure 49 claims. It was three times as important as the distance band and twice as important as zoning (Table 6). The weight values were then used to combine all criteria into a single map using a weighted overlay. Finally, we automated the geoprocessing routine using a Python script.

Table 6. Results of the pairwise analytical hierarchy process (AHP) for each spatial variable incorporated into the final graded map that guides the allocation of new urban land cover grid cells in three scenarios of increased urbanization.

\begin{tabular}{|c|c|c|c|c|c|c|c|c|}
\hline & $\begin{array}{c}\text { Urban } \\
\text { Growth } \\
\text { Boundary } \\
\text { (UGB) }\end{array}$ & $\begin{array}{l}\text { UGB } \\
\text { Dist. }\end{array}$ & Zoning & $\begin{array}{l}\text { Prime } \\
\text { Farm } \\
\text { Soils }\end{array}$ & $\begin{array}{c}\text { Groundwater } \\
\text { Restriction } \\
\text { Zones }\end{array}$ & $\begin{array}{c}\text { Measure } \\
49 \text { Claims }\end{array}$ & $\begin{array}{c}\text { Geometric } \\
\text { Mean }\end{array}$ & Weight \\
\hline \multicolumn{9}{|l|}{ Urban Growth } \\
\hline $\begin{array}{c}\text { Boundary } \\
\text { (UGB) }\end{array}$ & 1 & 3 & 2 & 9 & 9 & 9 & 4.04 & $44 \%$ \\
\hline UGB Distance & $1 / 3$ & 1 & $1 / 2$ & 7 & 9 & 5 & 1.94 & $21 \%$ \\
\hline Zoning & $1 / 2$ & 2 & 1 & 9 & 7 & 1 & 1.99 & $21 \%$ \\
\hline $\begin{array}{l}\text { Prime Farm } \\
\text { Soils }\end{array}$ & $1 / 9$ & $1 / 7$ & $1 / 9$ & 1 & $1 / 3$ & $1 / 7$ & 0.21 & $2 \%$ \\
\hline \multicolumn{9}{|l|}{ Groundwater } \\
\hline $\begin{array}{l}\text { Restriction } \\
\text { Zones }\end{array}$ & $1 / 9$ & $1 / 9$ & $1 / 7$ & 3 & 1 & 5 & 0.55 & $6 \%$ \\
\hline $\begin{array}{c}\text { Measure } 49 \\
\text { Claims }\end{array}$ & $1 / 9$ & $1 / 5$ & 1 & 7 & $1 / 5$ & 1 & 0.56 & $6 \%$ \\
\hline Total & & & & & & & 9.29 & $100 \%$ \\
\hline
\end{tabular}

The AHP determines the weight value of each variable to be used in a weighted overlay GIS procedure.

\section{Results}

Our consultation with stakeholders in the study area resulted in a simple storyline. Future urbanization will be placed in the study area where land use regulations allow it to be placed. The urban growth boundary and its planned extensions are the primary factor, but other factors, like zoning, high value farm soils, groundwater restriction zones and Measure 49 claims will also play a role. This qualitative data was transferred to a GIS process through spatial datasets, demarcating where those regulations are enforced. The amount of new urban land cover is harder to address, but a good rule of thumb is to assume population growth will be the main determinant. This is the historical 
precedent. A suggested range of quantitative values of population growth were used to select low, medium and high urban LULC growth. This basic process produced three maps of urban LULC growth.

Figure 5. Maps representing potential future urban land cover change in the study area. The insets represent a portion of the study area showing growth adjacent to the city of Hillsboro, OR.
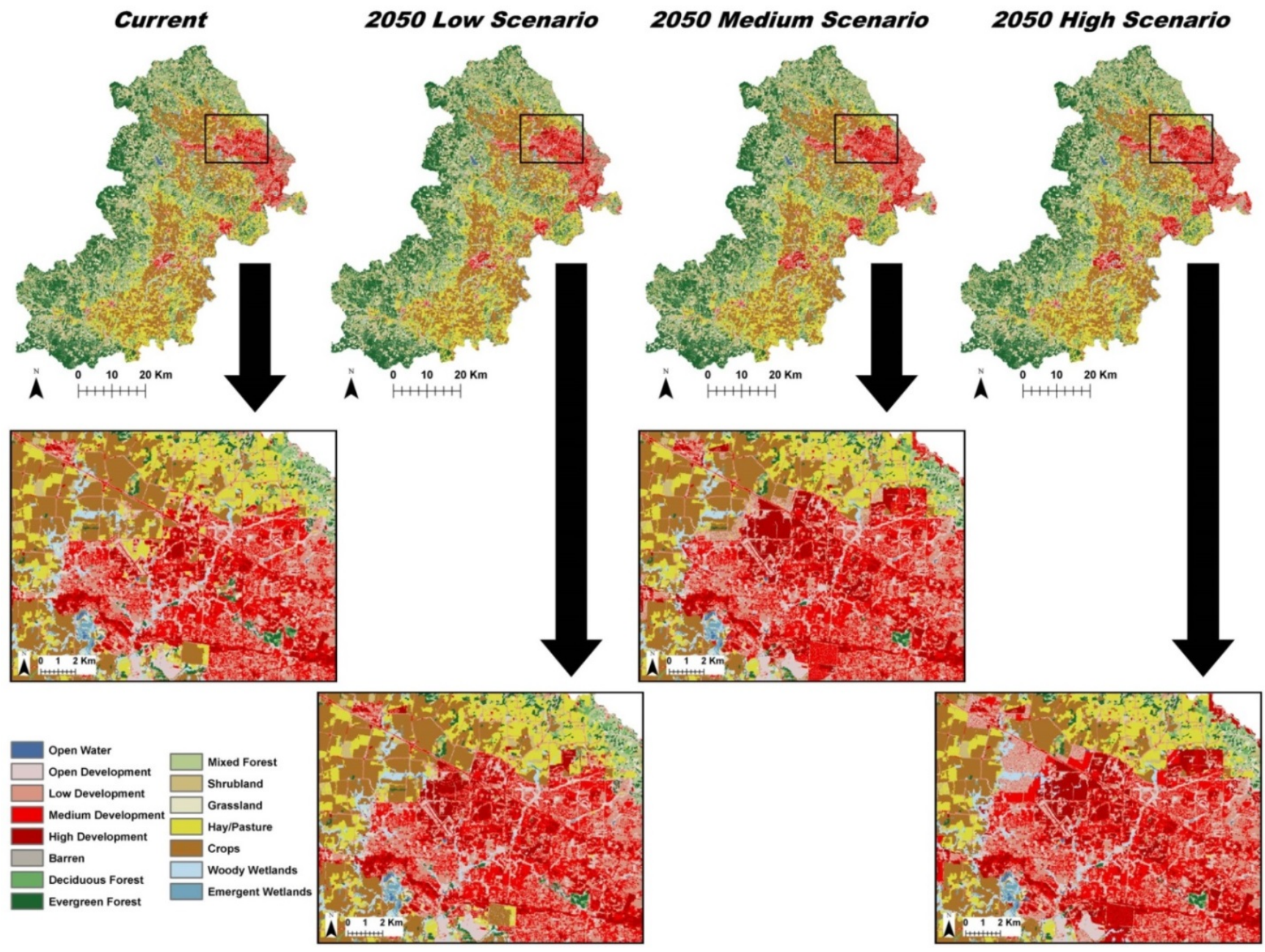

The three scenarios maps (Figure 5) showed development increasing along the current urban fringe. In the low scenario, the northern edge of the west side of the Portland metro area exhibited the most land consumption (Figure 5). The municipality in this area is actively planning for growth as a hub for the technology industry. The spatial regulatory data attracted commercial/industrial or high developed land cover here in all scenarios. Other areas also received growth resembling a "creep" around the edges of the current UGB to accommodate additional housing. This expansion intensified in the medium scenario as commercial/industrial land cover increases more substantially in other areas, including the southern portion of the Portland metro region, as well as the satellite communities in and near the Yamhill basin.

In the high scenario, a large portion of urban reserves were consumed around the western Portland metro area. The southern communities also showed a substantial increase in urban land, and even some of the smaller communities displayed gains. This was illustrated by two of the southern communities 
beginning to merge (Figure 6). The rural areas and very small communities exhibited very little change over the next forty years considering the very modest growth rates placed on them. This is consistent with the planning goals mentioned in the workshop. The simple modeling approach led to unrealistic patterns at the fine scale (Figure 7). Adding refinements to the modeling procedure was not feasible to rectify these discrepancies. The two planning stakeholders reviewed the final maps and confirmed the lack of realistic patterns at this scale. However, at the landscape scale, they agreed that the maps are plausible. The stakeholder representing agriculture also considered the maps plausible. Considering that this is the scale of analysis that we were most interested in projecting, we felt additional effort to address these issues was not warranted. At a subsequent meeting where the land cover results were presented as a small component of a greater project, we were able to communicate quickly and effectively how scenarios were produced.

Figure 6. Inset maps of potential land cover change in the study area focusing on the area encompassing the cities of Newberg (center of inset) and Dundee (southwest quadrant).

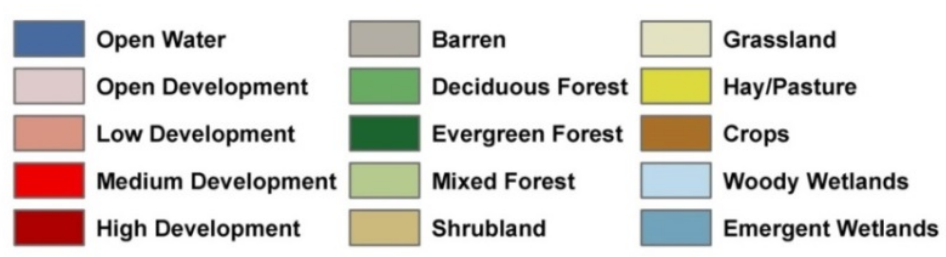

Low 2050

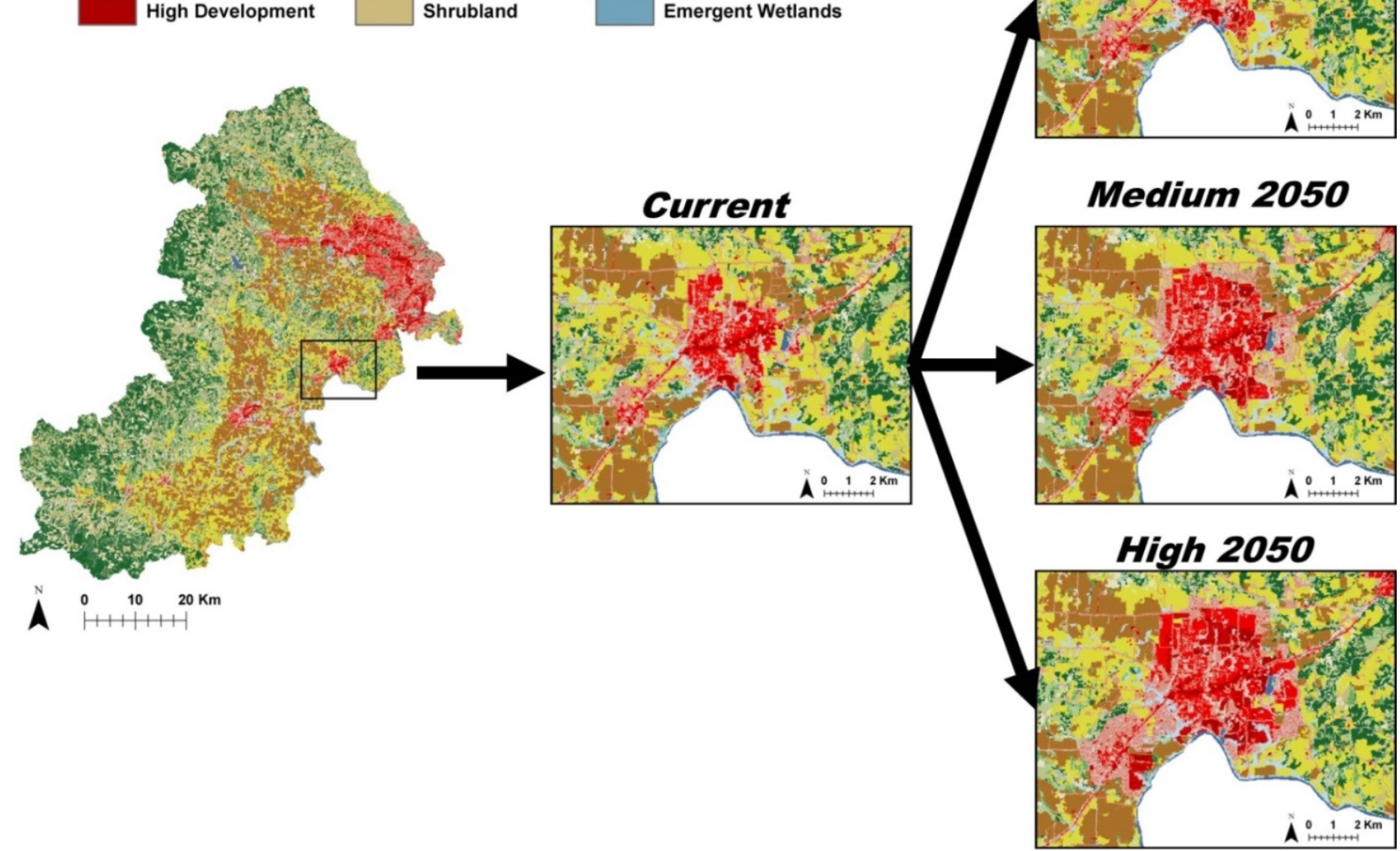


Figure 7. Example of grid cell raster mosaic phenomena depicting potential future land cover change. Exact arrangement of grid cells is determined randomly where there are more candidate pixels for transformation than are required.

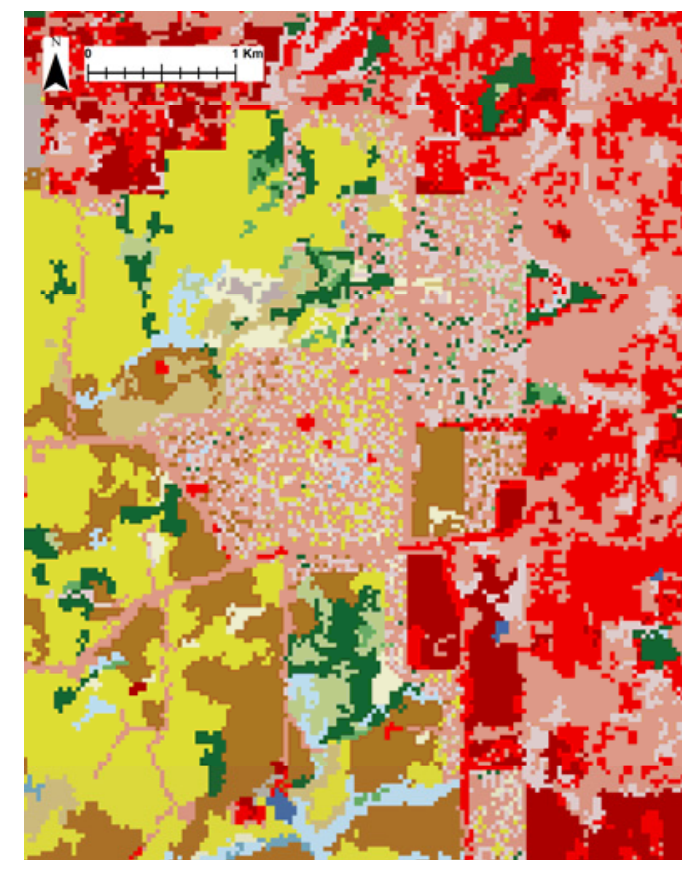

\section{Discussion}

This research presents a model of LULC change that provides a plausible answer to our research question of where and how much new urban growth will occur in the urbanizing basins of Oregon. Our expectation was that this simple modeling method could be disseminated easily to stakeholders with at least some familiarity with the geospatial sciences and the characteristics of spatial data. It was our intention to reduce the number of decisions necessary to build and parameterize the model in order to produce maps relatively rapidly. Our final product is not as consistent as those produced through data gathered in a demanding iterative storyline process [15,18,21] or a well-designed role playing game [19,47]. Instead, we gathered qualitative data through an ad hoc workshop and select interviews to develop a simple storyline, which is used elsewhere [48]. The maps can still prove useful as input in further scenario modeling. Considering uncertainty is inherently high in projecting future land conversions, the consistency of the maps is sufficient at the landscape scale. Other modeling approaches, like agent-based systems or cellular automata, may address complexity with more sophistication [49], but also produce a more complex message to explain, leading to additional time investment.

At the workshop where results were presented, members unfamiliar with the process understood it quickly. We aimed for a simple, flexible model that facilitates communication about complex relationships among stakeholders with varying backgrounds [13]. Their comprehension led to questioning an underlying assumption used to produce the final map outputs. Unsurprisingly, it was an assumption based on our judgment: a similar proportion of urban land cover intensities in the future as in the current LULC map. This points out a problem our study shares with others. GIS modeling processes are difficult to fully parameterize with participatory data. This leads to the use of researcher discretion in modifying parameters or to assuming similar values across all scenarios [50]. We 
attempted to counteract this by relying on the opinion of at least some of the initial stakeholders for the validation of our results. This is similar to the "social validation" approach taken by others [47]. Their agreement that the maps are plausible at the landscape scale lends support to their viability as input in certain applications.

Our consultation process left us with a narrative about increased urban growth and largely assumed other types of land conversions would be minimal to non-existent in our study area. Had various groups with differing perspectives been consulted over the course of a longer process, other factors addressing LULC change in rural areas could have potentially been identified. Even with the urban focus, other variables are likely important. Although deemed not important at the workshop, transportation networks could still be an important driver of land cover change [51]. Groundwater restriction zones, while having real consequences in rural lands, may not be a severe impediment to growth in urban land, since they are fed by surface supplies in our study area [52]. Additionally, stakeholders mentioned infrastructure access variables (e.g., water, sewer, gas lines) as having huge consequences on the location of new development, but data access has proven difficult. Using a few economic/demographic variables as parameters determining the amount of growth is simple and straightforward to communicate. This approach does not account for the dynamic nature of land supply and the spatially variable nature of demand. Our stakeholders pointed out that this is a major factor in urban planning. Our model assumes that as population grows, so will urban development. However, there are concerns that the land use regulations the model is based on will make property values unaffordable to many residents, leading to growth in communities outside of the study area, but still commutable to the employment centers within it. Econometric models based on assumptions of land owner decisions to maximize net returns from land can potentially address some of these issues $[53,54]$.

This analysis hinges on Oregon's land use system being the largest variable in guiding future land conversion in the state, barring any major government policy shifts over the next several decades. Indeed, the analysis already performed by local agencies in defining the current UGB, as well as URAs is what makes the following analysis a practical approach for developing these land cover scenarios and can be thought of as an extension of these efforts [55]. The heavy debt of this work means that a model based on land use regulations will not be generalizable to other regions. What is presented here may indeed rely too much on regulations, considering the land use systems have seen real challenges to their authority [56]. It must then be acknowledged that our scenarios used present conventional assumptions held by stakeholders in the region that aided a relatively quick process of parameterizing our land change model. In this sense, our scenarios are in reality a gradient of outcomes for a single storyline: land use regulations will be the dominant factor in deciding where new urban land will be located. More time and creative thinking would be necessary to develop other alternative possible future realities that aid in planning for the unpredictable [57], but would then challenge the framework for linking qualitative and quantitative data [16]. This issue, in fact, did come up in our workshop, where one member challenged the idea that future urbanization will follow the previous paradigm of what is developed land cover. Stressing technological innovations and social demands, we cannot simply assume that urban lands will impact natural systems through the loss of biota, increased impermeable surfaces, etc., as they did before. Exploring a scenario with these compelling qualitative factors would necessitate a much increased effort to develop a LULC map matching such a vision. 


\section{Conclusions}

The method presented in this paper offers a simplified and transparent approach for producing future land cover scenario maps. Our process contains important stakeholder involvement that was integral to identifying and prioritizing the factors that drove new urban growth in the model. Our main objective was to develop a straightforward process that was easy to communicate. We make several observations describing the degree of success we obtained in our study.

(1) Although simple, our land cover projection requires the use of a quantitative GIS process to actually produce the maps, so it still faces the same issues of other scenario modeling efforts when translating qualitative data to quantitative.

(2) Keeping the stakeholder consultation limited is advantageous, because it allows researchers to model future land cover under manageable time and effort constraints with widely available GIS data. Our land cover scenarios represent a gradient of potential realities based on the same storyline, and researchers still needed to make assumptions and set some of the parameters themselves.

(3) The stakeholder consultation led to place specific analysis (e.g., different growth rates for urban $v s$. rural areas). The land use regulatory system is unique to Oregon, and the spatial data based on it encapsulates a great deal of external analysis that made our process faster. This highlights the potential difficulty in generalizing scenario development frameworks that facilitate reproducibility [15].

Ultimately, we acquired an answer to our pressing research question of where will new urban growth be placed and how much of it will there be. We conclude that developed land will consume portions of the metropolitan fringe, and its amount will be determined by how much population will be present in the area by 2050 . The case study points out that a relatively simple GIS-based modeling process is possible given available data, but this also leads to sacrificing some complex dynamic processes of land cover change. Therefore, this effort represents an initial step in modeling land cover in our study area, and further modifications and refinements to the participatory framework and to the model itself are warranted.

\section{Acknowledgments}

This research was supported by the U.S. National Science Foundation, grant \#1226629, and by the Institute for Sustainable Solutions at Portland State University. We would like to thank John Barnes of the City of McMinnville Planning Department, Bob Harmon of the Oregon Department of Water Resources, Lesley Hegewald of the Mid-Willamette Valley Council of City Governments, Sarah Marvin of the Oregon Department of Land Conservation and Development and Jan Wolf of the City of Newberg Engineering Department for providing GIS data for our study area. We would like to thank the members of the workshop for their invaluable input and for their helpful comments. The views expressed are our own and do not necessarily reflect those of sponsoring agencies. 


\section{Author Contributions}

R.W.H. and H.C. conceived and designed the presented research. R.W.H. and H.C. both consulted with stakeholder participants. R.W.H. performed the research and analyzed the data. R.W.H. and H.C. wrote the paper.

\section{Conflicts of Interest}

The authors declare no conflict of interest.

\section{References}

1. Millennium Ecosystem Assessment (MA). Ecosystems and Human Well-Being; Island Press: Washington, DC, USA, 2005.

2. Foley, J.A.; DeFries, R.; Asner, G.P.; Barford, C.; Bonan, G.; Carpenter, S.R.; Chapin F.S.; Coe, M.T.; Daily, G.C.; Gibbs, H.K.; et al. Global consequences of land use. Science 2005, 309, $570-574$.

3. Seto, K.C.; Güneralp, B.; Hutyra, L. Global forecasts of urban expansion to 2030 and direct impacts on biodiversity and carbon pools. Proc. Natl. Acad. Sci. USA 2012, 109, 16083-16088.

4. Gulickx, M.M.C.; Verburg, P.H.; Stoorvogel, J.J.; Kok, K.; Veldkamp, A. Mapping landscape services: A case study in a multifunctional rural landscape in the Netherlands. Ecol. Indic. 2013, 24, 273-283.

5. Turner, B.L.; Lambin, E.F.; Reenberg, A. The emergence of land change science for global environmental change and sustainability. Proc. Natl. Acad. Sci. USA 2007, 104, 20666-20671.

6. Thompson, J.R.; Wiek, A., Swanson, F.J.; Carpenter, S.R.; Hollingsworth, T.; Spies, T.A.; Foster, D.R. Scenario studies as a synthetic and integrative research activity for long-term ecological research. BioScience 2012, 62, 367-376.

7. Bateman, I.J.; Harwood, A.R.; Mace, G.M.; Watson, R.T.; Abson, D.J.; Andrews, B.; Binner, A.; Crowe, A.; Day, B.H.; Dugdale, S.; et al. Bringing ecosystem services into economic decisionmaking: Land use in the United Kingdom. Science 2013, 341, 45-50.

8. Goldstein, J.H.; Caldarone, G.; Duarte, T.K.; Ennaanay, D.; Hannahs, N.; Mendoza, G.; Polasky, S.; Wolny, S.; Daily G.C. Integrating ecosystem-service tradeoffs into land-use decisions. Proc. Natl. Acad. Sci. USA 2012, 109, 7565-7570.

9. Boody, G.; Vondracek, B.; Andow, D.A.; Krinke, M.; Westra, J.; Zimmerman, J.; Welle, P. Multifunctional agriculture in the United States. BioScience 2005, 55, 27-38.

10. Santelmann, M.V.; White, D.; Freemark, K.; Nassauer, J.I.; Eilers, J.M.; Vaché, K.B.; Danielson, B.J.; Corry, R.C.; Clark, M.E.; Polasky, S.; et al. Assessing alternative futures for agriculture in Iowa, U.S.A. Landsc. Ecol. 2004, 19, 357-374.

11. Waldhardt, R.; Bach, M.; Borresch, R.; Breuer, L.; Diekötter, T.; Frede, H.; Gäth, S.; Ginzler, O.; Gottschalk, T.; Julich, S.; et al. Evaluating today's landscape multifunctionality and providing an alternative future: A normative scenario approach. Ecol. Soc. 2010, 15, 30:1-30:20.

12. Price, J.; Silbernagel, J.; Miller, N.; Swaty, R.; White, M.; Nixon, K. Eliciting expert knowledge to inform landscape modeling of conservation scenarios. Ecol. Model. 2012, 229, 76-87. 
13. Westervelt, J.; BenDor, T.; Sexton, J. A technique for rapidly forecasting regional urban growth. Environ. Plan. B: Plan. Des. 2011, 38, 61-81.

14. Patel, M.; Kok, K.; Rothman, D.S. Participatory scenario construction in land use analysis: An insight in the experiences created by stakeholder involvement in the northern Mediterranean. Land Use Policy 2007, 24, 546-561.

15. Alcamo, J. The SAS approach: Combining qualitative and quantitative knowledge in environmental scenarios. In Environmental Futures: The Practice of Environmental Scenario Analysis; Alcamo, J., Ed.; Elsevier: Amsterdam, The Netherlands, 2008; pp. 123-150.

16. Kok, K. The potential of fuzzy cognitive maps for semi-quantitative scenario development, with an example from Brazil. Glob. Env. Chang. 2009, 19, 122-133.

17. Walz, A.; Lardelli, C.; Behrendt, H.; Grêt-Regamey, A.; Lundström, C.; Kytzia, S.; Bebi, P. Participatory scenario analysis for integrated regional modelling. Landsc. Urban Plan. 2007, 81, 114-131.

18. Swetnam, R.D.; Fisher, B.; Mbilinyi, B.P.; Munishi, P.K.T.; Willcock, S.; Ricketts, T.; Mwakalila, S.; Balmford, A.; Burgess, N.D.; Marshall, A.R.; et al. Mapping socio-economic scenarios of land cover change: A GIS method to enable ecosystem service modelling. J. Environ. Manag. 2011, 92, 563-574.

19. Lamarque, P.; Artaux, A.; Barnaud, C.; Dobremez, L.; Nettier, B.; Lavorel, S. Taking into account farmers' decision making to map fine-scale land management adaptation to climate and socio-economic scenarios. Landsc. Urban Plan. 2013, 119, 147-157.

20. Koschke, L.; Fürst, C.; Frank, S.; Makeschin, F. A multi-criteria approach for an integrated land-cover-based assessment of ecosystem services provision to support landscape planning. Ecol. Indic. 2012, 21, 45-56.

21. Hulse, D.W.; Branscomb, A.; Payne, S.G. Envisioning alternatives: Using citizen guidance to map future land and water use. Ecol. Appl. 2004, 4, 325-341.

22. Oregon Blue Book. City and County Populations. Available online: http://bluebook.state.or.us/ local/populations/populations.htm (accessed on 21 August 2013).

23. Oregon Metro. 20 and 50 Year Regional Employment and Population Range Forecasts. Available online: http://library.oregonmetro.gov/files/20-50_range_forecast.pdf (accessed on 4 April 2013).

24. Portland State University College of Urban and Public Affairs Population Research Center. Population Estimates. Available online: http://www.pdx.edu/prc/population-estimates-0 (accessed on 19 August 2013).

25. Fry, J.A; Coan, M.J.; Homer, C.G.; Meyer, D.K.; Wickham, J.D. Completion of the National Land Cover Database (NLCD) 1992-2001 Land Cover Retrofit Product. Available online: http://pubs.usgs.gov/of/2008/1379/pdf/ofr2008-1379.pdf (accessed on 13 January 2014).

26. Fry, J.; Xian, G., Jin, S.; Dewitz, J.; Homer, C.; Yang, L.; Barnes, C; Herold, N.; Wickham, J. Completion of the 2006 National Land Cover Database for the conterminous United States. Photgramm Eng. Remote Sens. 2011, 77, 858-864.

27. Lambin, E.F.; Turner, B.L., Geist, H.J.; Agbola, S.B.; Angelsen, A.; Bruse, J.W.; Coomes, O.T.; Dirzo, R.; Fischer, G.; Folke, C.; et al. The causes of land use and land cover change: Moving beyond myths. Glob. Environ. Chang. 2001, 11, 261-269. 
28. Planning the Oregon Way: A Twenty-Year Evaluation; Abbot, C., Howe, D., Adler, S., Eds.; Oregon State University Press: Corvallis, OR, USA, 1994.

29. Oregon Department of Land Conservation and Development. Ballot Measures 37 (2004) and 49 (2007) Outcomes and Effects. Available online: http://www.oregon.gov/LCD/docs/publications/ m49_2011-01-31.pdf (accessed on 1 April 2013).

30. Oregon Department of Land Conservation and Development. Metro Urban and Rural Reserves. Available online: http://www.oregon.gov/LCD/Pages/metro_urban_and_rural_reserves.aspx (accessed on 1 April 2013).

31. Boeder, M.; Chang, H. Multi-scale analysis of oxygen demand trends in an urbanizing Oregon watershed, USA. J. Environ. Manag. 2008, 87, 567-581.

32. Praskievicz, S.; Chang, H. Impacts of climate change and urban development on water resources in the Tualatin River basin, Oregon. Ann. Assoc. Am. Geogr. 2011, 101, 249-271.

33. Oregon Department of Environmental Quality. Tualatin Subbasin Total Maximum Daily Load and Water Quality Management Plan: Chapter 1-Overview and Background. Available online: http:/www.deq.state.or.us/wq/tmdls/docs/willamettebasin/tualatin/revision/Ch0CoverExecSummary.pdf (accessed on 3 March 2013).

34. Pratt, B.; Chang, H. Effects of land cover, topography, and built structure on seasonal water quality at multiple spatial scales. J Haz. Mater. 2012, 209/210, 48-58.

35. Chang, H.; Thiers, P.; Netusil, N.; Yeakley, J.A.; Rollwagon-Bollens, G.; Bollens, S.M. Relationship between environmental governance and water quality in a growing metropolitan area of the Pacific Northwest, USA. Hydro. Earth Syst. Sci. 2014, in press.

36. Oregon Metro. RLIS Live, Geographic Information System Data. Available online: http://www.oregonmetro.gov/index.cfm/go/by.web/id=593 (accessed on 21 August 2013).

37. City of Dayton, Oregon. Planning Atlas and Comprehensive Plan. Available online: http://www.ci.dayton.or.us/vertical/sites/\%7B0813AE62-E15F-4C65-858B-10DDF2ABA1FE\% 7D/uploads/Complete_Copy_3-31-11.pdf(accessed on 11 March 2014).

38. Oregon Spatial Data Library. Available online: http://spatialdata.oregonexplorer.info/geoportal/ catalog/main/home.page (accessed on 21 August 2013).

39. USFWS Geospatial Services. USFWS National Cadastral Data. Available online: http://www.fws.gov/GIS/data/CadastralDB/index.htm (accessed on 21 August 2013).

40. Oregon Water Resources Department. Water Protections and Restrictions. Available online: http://www.oregon.gov/owrd/pages/pubs/aquabook_protections.aspx (accessed on 21 August 2013).

41. Oregon State Archives. Department of Land Conservation and Development. Division 33. Agricultural Land. Available online: http://arcweb.sos.state.or.us/pages/rules/oars_600/oar_660/ 660_033.html (accessed on 27 September 2013).

42. U.S. Census Bureau. Profile of General Population and Housing Characteristics: 2010. Geography: Portland-Vancouver-Hillsboro, OR-WA Metro Area (part); Oregon, USA. Available online: $\quad \mathrm{http} / /$ factfinder2.census.gov/faces/tableservices/jsf/pages/productview.xhtml?pid= DEC_10_DP_DPDP1\&prodType=table (accessed on 19 August 2013).

43. U.S. Bureau of Labor Statistics. Local Area Employment Statistics, U.S. Department of Labor. Available online: http://data.bls.gov/cgi-bin/dsrv (accessed on 19 August 2013). 
44. Oregon Metro. The Nature of 2040: The Region's 50-Year Plan for Managing Growth. Available online: http://library.oregonmetro.gov/files/natureof2040.pdf (accessed on 28 January 2014).

45. Environmental Science Research Institute. ArcGIS 10.1.; Environmental Science Research Institute: Redlands, CA, USA, 2010.

46. Saaty, T.L. The Analytic Hierarchy Process: Planning, Priority Setting, Resource Allocation; McGraw-Hill: New York, NY, USA, 1980.

47. Castella, J.; Trung, T.N.; Boissau, S. Participatory simulation of land-use changes in the northern mountains of Vietnam: The combined use of an agent-based model, a role-playing game, and a geographic information system. Ecol. Soc. 2005, 10, 27:1-27:32.

48. Rounsevell, M.D.A.; Ewert, F.; Reginster, I.; Leemans, R.; Carter, T.R. Future scenarios of European agricultural land use II. Projecting changes in cropland and grassland. Agric. Ecosyst. Environ. 2005, 107, 117-135.

49. Parker, D.C.; Manson, S.M.; Janssen, M.A.; Hoffman, M.J.; Deadman, P. Multi-agent systems for the simulation of land-use and land-cover change: A review. Ann. Assoc. Am. Geogr. 2003, 93, 314-337.

50. Kok, K.; van Delden, H. Combining two approaches of integrated scenario development to combat desertification in the Guadalentín Watershed, Spain. Environ. Plan. B: Plan Des. 2009, 36, 49-66.

51. Southworth, J.; Marsik, M.; Qiu, Y.; Perz, S.; Cumming, G.; Stevens, F.; Rocha, K.; Duchelle, A.; Barnes, G. Roads as drivers of change: Trajectories across the tri-national frontier in MAP, the southwestern Amazon. Remote Sens. 2011, 3, 1047-1066.

52. Kelley, S. (Washington County Land Use and Transportation Department, Hillsboro, OR, USA). Personal communication, 15 November 2012.

53. Radeloff, V.C.; Nelson, E.; Plantinga, A.J.; Lewis, D.J.; Helmers, D.; Lawler, J.J.; Withey, J.C.; Beaudrey, R.; Martinuzzi, S.; Butsic, V.; et al. Economic-based projections of future land use in the coterminous Unites States under alternative policy scenarios. Ecol. Appl. 2012, 22, 1036-1049.

54. Suarez-Rubio, M.; Lookingbill, T.R.; Wainger, L.A. Modeling exurban development near Washington, DC, USA: Comparison of a pattern based model and spatially-explicit econometric model. Landsc. Ecol. 2012, 27, 1045-1061.

55. Yee, D. (Oregon Metro, Portland, OR, USA). Personal communication, 11 July 2013.

56. Walker, P.A.; Hurley, P.T. Planning Paradise: Politics and Visioning of Land Use in Oregon; The University of Arizona Press: Tucson, AZ, USA, 2011.

57. Peterson, G.D.; Cumming, G.S.; Carpenter, S.R. Scenario planning: A tool for conservation planning in an uncertain world. Conserv. Biol. 2003, 179, 358-366.

(C) 2014 by the authors; licensee MDPI, Basel, Switzerland. This article is an open access article distributed under the terms and conditions of the Creative Commons Attribution license (http://creativecommons.org/licenses/by/3.0/). 